\title{
Investigation into the healing properties of walnut (Tetracarpidium conophorum) leaf and onion (Allium cepa) bulb residues in Clarias gariepinus
}

\author{
Investigación de las propiedades cicatrizantes de la hoja de nogal (Tetracarpidium conophorum) \\ y residuos de bulbo de cebolla (Allium cepa) en Clarias gariepinus
}

\author{
OS Bello ${ }^{\mathrm{a}}$, BO Emikpe ${ }^{\mathrm{b}}$, AK Olaifa ${ }^{\mathrm{c}}, \mathrm{FE}$ Olaifa $^{\mathrm{a}}$
}

${ }^{a}$ Department of Aquaculture and Fisheries Management, University of Ibadan, Nigeria.

${ }^{b}$ Department of Veterinary Pathology, University of Ibadan, Nigeria.

'Department of Veterinary Surgery and Reproduction, University of Ibadan, Nigeria.

\begin{abstract}
RESUMEN
El presente estudio evaluó el efecto de la inclusión en la dieta de distintos niveles de hojas nogal (WL) y residuos de bulbo de cebolla (OB) sobre la cicatrización de heridas en la dermis de Clarias gariepinus. El experimento se llevó a cabo en nueve tanques experimentales (1,8 m x $2 \mathrm{~m}$ x 1,2 m) durante 14 días. Se formularon nueve dietas experimentales al $40 \%$ de proteína bruta con los siguientes niveles de inclusión: control (0\%), OB2 (0,5\%), OB3 $(1,0 \%)$, OB4 (1,5\%), OB5 (2,0\%), WL6 (0,5\%), WL7 (1,0\%), WL8 (1,5\%) y WL9 $(2,0 \%)$. Los peces (peso promedio $1 \mathrm{~kg})$ fueron alimentados dos veces al día con $3 \%$ del peso corporal. El porcentaje de cicatrización y la tasa diaria de cicatrización en las zonas laterales y caudales de macho y hembra de Clarias gariepinus se investigaron a los 0, 7 y 14 días. Los datos fueron analizados mediante estadística descriptiva y ANOVA (P <0,05). Los resultados mostraron que los peces alimentados con hojas de nogal y residuos de bulbo de cebolla mostraron un mejor rendimiento que el control. La cicatrización dermal de heridas en Clarias gariepinus fue mejor en la parte lateral y caudal (100\%; 14,29\%; 100\%; 14,29\%) en WL 8 en comparación con el control $(98 \% ; 14,00 ; 80 \% ; 11,43)$, respectivamente. Clarias gariepinus macho tenía una mejor cicatrización en comparación con la hembra (100\%; $14,29 ; 82 \% ; 11,71)$, respectivamente. Las dietas con hojas de nogal y residuos de bulbo de cebolla tienen propiedades curativas y podrían ser usadas en acuicultura, además la inclusión de un 1,5\% de nogal en la alimentación de los peces favorece la cicatrización de heridas en Clarias gariepinus.
\end{abstract}

Palabras clave: Clarias gariepinus, hoja de Nogal, bulbo de cebolla, cicatrización de heridas.

\section{SUMMARY}

The study evaluated the effect of dietary inclusion levels of walnut leaf (WL) and onion bulb (OB) residues on dermal wound healing of Clarias gariepinus. The experiment was carried out in 9 experimental tanks $(1.8 \mathrm{~m} \mathrm{x} 2 \mathrm{~m} \mathrm{x} 1.2 \mathrm{~m})$ for 14 days. Nine experimental diets were formulated at $40 \%$ crude protein representing the following inclusion levels: Control (0\%), OB2 (0.5\%), OB3 (1.0\%), OB4 (1.5\%), OB5 (2.0\%), WL6 (0.5\%), WL7 $(1.0 \%)$, WL8 $(1.5 \%)$ and WL9 $(2.0 \%)$. Fish (mean weight of $1 \mathrm{~kg}$ ) were fed twice daily at 3\% body weight. Percentage healing and daily healing rate on lateral and caudal parts of the male and female Clarias gariepinus were investigated at 0,7 and 14 days. Data were analysed using descriptive statistics and ANOVA at $\mathrm{P}<0.05$. The results demonstrated that the fish fed with walnut leaf and onion bulb residues showed better performance than the control. Dermal wound healing of Clarias gariepinus was better on lateral and caudal parts $(100 \%, 14.29 ; 100 \%, 14.29)$ in WL 8 compared to the control $(98 \%$, $14.00 ; 80 \%, 11.43)$ respectively. The results obtained showed that the male Clarias gariepinus had better healing compared to the female (100\%, 14.29 ; $82 \%, 11.71)$, respectively. Diets with walnut leaf and onion bulb residues had wound healing properties and they could be use in fish farming. Also, the inclusion of $1.5 \%$ of walnut leaf residue in fish feed promotes wound healing in Clarias gariepinus.

Key words: Clarias gariepinus, walnut leaf, onion bulb, wound healing.

\section{INTRODUCTION}

African catfish (Clarias gariepinus) is one of many economical freshwater fishes that are cultured in Nigeria for its excellent biological characteristics such as fast growth, popular taste and high economic value. Unfortunately, high mortality acts as an important limiting factor for aquaculture businesses as result of wound and

Accepted: 02.05.2013.

* banabis2001@yahoo.com; bo.emikpe@mail ui.edu.ng infections sustained by the fish. Wound has been defined as a disruption of normal anatomical structure and more importantly function. Therefore, healing is the complex and dynamic process that results in the restoration of anatomical continuity and function (Lazarus et al 1994).

A wound may be produced by chemical, physical, thermal, microbial or immunological action on the tissue, causing discomfort and making it more prone to infection and other troublesome complications (Ingold 1993). Wounds normally heal in a very orderly and efficient manner characterised by four distinct, but overlapping 
phases: haemostasis, inflammation, proliferation and remodelling. Many of the synthetic drugs currently used for the treatment of wounds are not only expensive but also pose problems such as allergy, drug resistance and this situation has forced the scientists to seek alternative drugs (Sai and Babu 1998). Efforts are being made all over the world to discover agents that can promote healing and therefore reduce high mortality, enhance productivity and improve high economic performance. Looking for less harmful approaches and more environmentally-friendly treatments became of major importance. Therefore, using medicinal plants seems to be an attractive alternative.

Medicinal plants have been known as first art of treatment to man and animals. Plants and their extracts have an immense potential for the management and treatment of wound. The phytomedicine for wound healing is not only cheap and affordable but are also purportedly safe as hypersensitive reactions are rarely encountered with the use of these agents. Medicinal plants such as onion bulb and walnut leaf had been used to combat infection and alleviate stress with a potential for wound healing and antimicrobial effects in animals (Lee et al 2009, Omale and Isaac 2010). Walnut (Tetracarpidium conophorum) belongs to the Euphorbiaceaae family. Some phytochemical constituents present in T. conophorum are tannins, protein oils, carbohydrates and fibres (Enujiagha 2003). Walnut is believed to have the following traditional uses; anthelminthic, antibacterial, antifungal, anti inflammatory, antiviral, immunostimulant and liver health maintenance (Blumenthal et al 2000). Also, onion forms a large genus of about 700 species of strong-smelling, bulbous or rhizomatous biennials and perennials (Deni 1996). In traditional medicine is used externally to treat boils, felons, wounds and stings and to relieve coughs, bronchitis, gastro-intestinal disorders and headache (Diah et al 1999). Onions contain many active compounds that appear to inhibit the growth of cancerous cells, lower blood pressure and cholesterol and stimulate immune response. Some studies have been carried out in the cyprinid species zebra fish (Danio rerio) and common carp (Cyprinus carpio) (Nakatani et al 2007, Gonzalez et al 2007, Yoshinari et al 2009, Lee et al 2009), Wister albino rats, Rattus novergicus (Omale and Isaac 2010) but research studies on African catfish, Clarias gariepinus have not been properly elucidated.

The purpose of this study was to investigate the potential effect of walnut leaf and onion bulb residues on dermal wound healing pattern in Clarias gariepinus and provide baseline data for future research in area of wound healing for Clarias gariepinus.

\section{MATERIAL AND METHODS}

\section{PLANT COLLECTION AND IDENTIFICATION}

Onion bulbs were purchased from Bodija market in Ibadan, Nigeria. Walnut leaf was obtained from a farm at Oka
-Akoko, Nigeria. They were authenticated at the herbarium of the Forestry Research Institute of Nigeria (FRIN), Ibadan, where a voucher specimen was deposited under FHI 107515.

\section{PREPARATION AND EXTRACTION OF PLANT MATERIALS}

Onion extraction. The onion bulbs were washed with distilled water and allowed to air dry at ambient temperature $\left(25^{\circ} \mathrm{C}\right)$ for one hour. The dry outer coverings of the onions were manually peeled off, washed and extracted as described by Azu and Onyeagba (2007). $200 \mathrm{~g}$ of the fresh onion bulbs were blended into fine powder and soaked in $100 \mathrm{ml}$ of $95 \%$ ethanol for $24 \mathrm{hrs}$. The obtained pulp was left in a clean, sterile glass container, shaken vigorously to allow for proper extraction, filtered using a sterile muslin cloth after which the residue was obtained, air-dried and stored $\left(4^{\circ} \mathrm{C}\right)$ until required.

Walnut leaf extraction. The extraction was as described by Ajaiyeoba and Fadare (2006). The air-dried walnut leaf were grounded with a hammer mill to fine powder. $200 \mathrm{~g}$ of the powder of walnut leaves was soaked in 100 $\mathrm{ml}$ of $80 \%$ methanol for 72 hours. Walnut leaf were properly mixed with methanol, filtered using a sterile muslin cloth after which the extract was obtained, air-dried and stored at $\left(25^{\circ} \mathrm{C}\right)$ until required.

\section{EXPERIMENTAL FISH}

The experiment was conducted at the Department of Aquaculture and Fisheries Management Teaching and Research Farm, University of Ibadan, Nigeria. Fifty four (54) adults' male and female Clarias gariepinus (27 each) with mean body weight of $1 \mathrm{~kg}$ of the same age were studied. The fish were randomly distributed into nine treatments with 6 fish per treatment. They were purchased from a known farm in Ibadan, Nigeria. The fish were acclimatised for six weeks before the experiment and judged to be of good general health based on complete physical examination which includes general body condition, the eye, gills and body examination before the commencement of the experiment.

\section{SURGICAL PROCEDURE}

Feeding were stopped 24 hours prior to surgery and the fish were anaesthetics shortly before the commencement of the experiment. The lateral and caudal parts of fish were aseptically prepared and this was conducted to determine if differences exist in the healing rate at different locations (lateral and caudal part) of fish. The wound location was chosen because the tissues of these locations vary from one another with incision of $1 \mathrm{~cm}^{2}$ on the fish body (Abo et al 2004, Bell 2002). A standard template (a transparent paper, drawing the site on a well 
uniform $1 \mathrm{~mm}$ cubic square quadrant) was placed on the fish and the cuts were made on the lateral and caudal part of the fish to draw the wound area (see figure 1) and was replicated twice on the fish body. Immediately after it is cut, the wound was photographed with a digital camera.

The fish were taken out of water on daily basis (everyday) to examine the wound closure. Measurement and reading were done on 0,7 and 14 days. Photographs were taken using digital camera with 8.2 mega pixel, $3 x$ optical zoom specifications while measurement was done using measuring scale for assessment of the wound closure on the lateral and caudal parts at 0,7 and 14 days adopting a two-dimensional healing measurements.

Percentage healing was calculated as:

$\%$ healing $=$ change in-wound area (area of regenerated tissue $) \times 100$ initial wound area

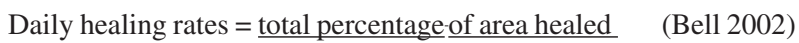
number of days with measurements taken

\section{EXPERIMENTAL DIETS}

Proximate composition of the experimental diet was $40.0 \%$ crude protein, $15.9 \%$ ether extract, $15.7 \%$ ash, $7.4 \%$ moisture, and $20.9 \%$ NFE. Nine experimental diets were prepared by incorporating walnut leaf and onion bulb residues at the following inclusion levels:

- Treatment 1: served as the control and without any treatment.

- Treatment 2: was treated with onion bulb residue $(0.5 \%)$

- Treatment 3: was treated with onion bulb residue (1.0\%)

- Treatment 4: was treated with onion bulb residue $(1.5 \%)$

- Treatment 5: was treated with onion bulb residue (2.0\%)

- Treatment 6: was treated with walnut leaf residue $(0.5 \%)$

- Treatment 7: was treated with walnut leaf residue (1.0\%)

- Treatment 8: was treated with walnut leaf residue (1.5\%)

- Treatment 9: was treated with walnut leaf residue (2.0\%).

Feed ingredients such as fishmeal, soybean, maize, starch, vegetable oil, Di calcium phosphate (DCP), salt and vitamin- mineral premix were added and the dry

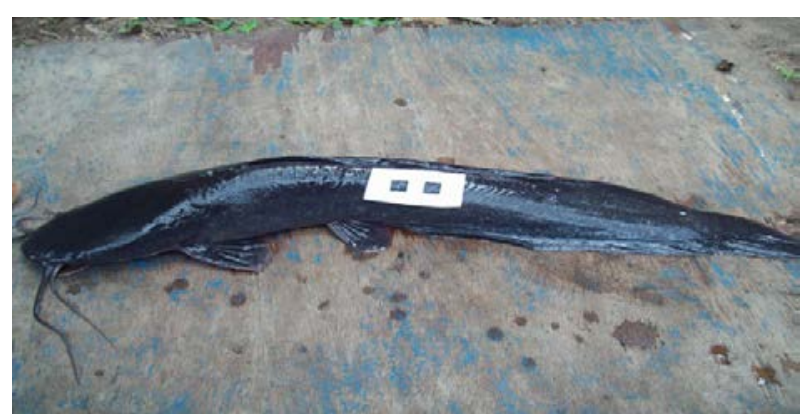

Figure 1. Clarias gariepinus with $1 \mathrm{~cm}^{2}$ template. Clarias gariepinus con plantilla de $1 \mathrm{~cm}^{2}$. ingredients were mixed thoroughly in a mixer for 10 minutes. Water was added and the resulting dough was pelletted, the pelletted diets were sun-dried, and stored in airtight containers at room temperature to prevent mycotoxin formation until required.

\section{STATISTICAL ANALYSIS}

Percentage healing and daily healing rate on caudal and lateral part of Clarias gariepinus resulting from the experiment were subjected to one-way analysis of variance (ANOVA) using SPSS (Statistical Package for Social Sciences 2006 version 15.0). Duncan multiple range test was used to compare differences among individual means.

\section{RESULTS}

Results showed that $C$. gariepinus with wounds on the lateral and caudal aspects had better healing percentages and daily healing rates in onion bulb and walnut leaf treatments than the control. Table 1 ( $a$ and $b$ ) shows that the highest value was recorded in OB4 while the lowest was recorded in OB5 among the onion bulb residue treatments, while the highest value was recorded in WL8 and the lowest in WL6 among the walnut leaf residue treatments for percentage healing. The highest value was also recorded in OB4 and the lowest in OB5 among the onion bulb treatment, and WL8 recorded highest and WL6 recorded the lowest value for walnut leaf residue on daily healing rate on lateral part on 7 days and $100 \%$, 14.29 for all the treatments on the lateral part on 14 days of healing percentage and daily healing rate, respectively.

Also, the healing percentage and daily healing rate of the caudal part of $\mathrm{C}$ gariepinus show better healing percentage and daily healing rate on onion bulb treatment and walnut leaves treatment than the control. The highest value was recorded in OB4 while the lowest was recorded in OB5 among the onion bulb residue treatment, while the highest value was recorded in WL8 and the lowest one in WL6 and WL7 among the walnut leaf residue treatment especially on the caudal part. The highest value was also recorded in OB4 and the lowest in OB5 among the onion bulb residue and WL8 recorded highest and lowest in WL6 and WL7 for walnut leaf residue on daily healing rate on caudal part on 7 days and OB4 recorded highest healing percentage and lowest in OB2 among onion bulb residue treatment while the highest value was recorded in WL8 and WL9 and lowest in WL6 and WL7 among walnut leaf residue treatment for healing percentage and highest value was recorded in OB4 and lowest in OB2 among the onion bulb residue treatment for daily healing rate while the highest was recorded in WL8 and WL9 and lowest in WL6 and WL7 for daily healing rate among the walnut leaf residue treatment on the caudal part on 14 days.

The results also revealed that male $C$. gariepinus healing percentage and daily healing rate were better in treated groups than the control. Table 2 ( $a$ and $b$ ) 


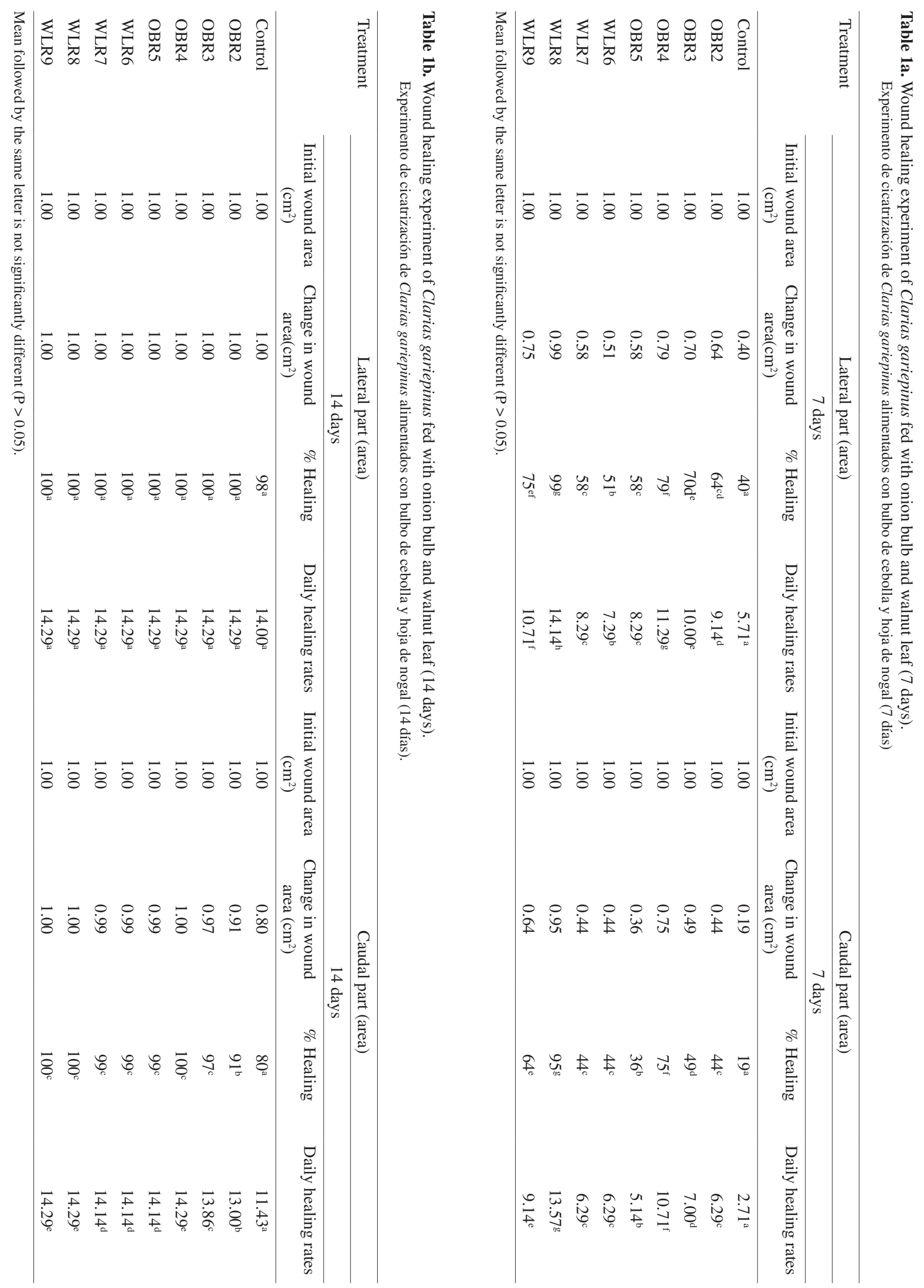



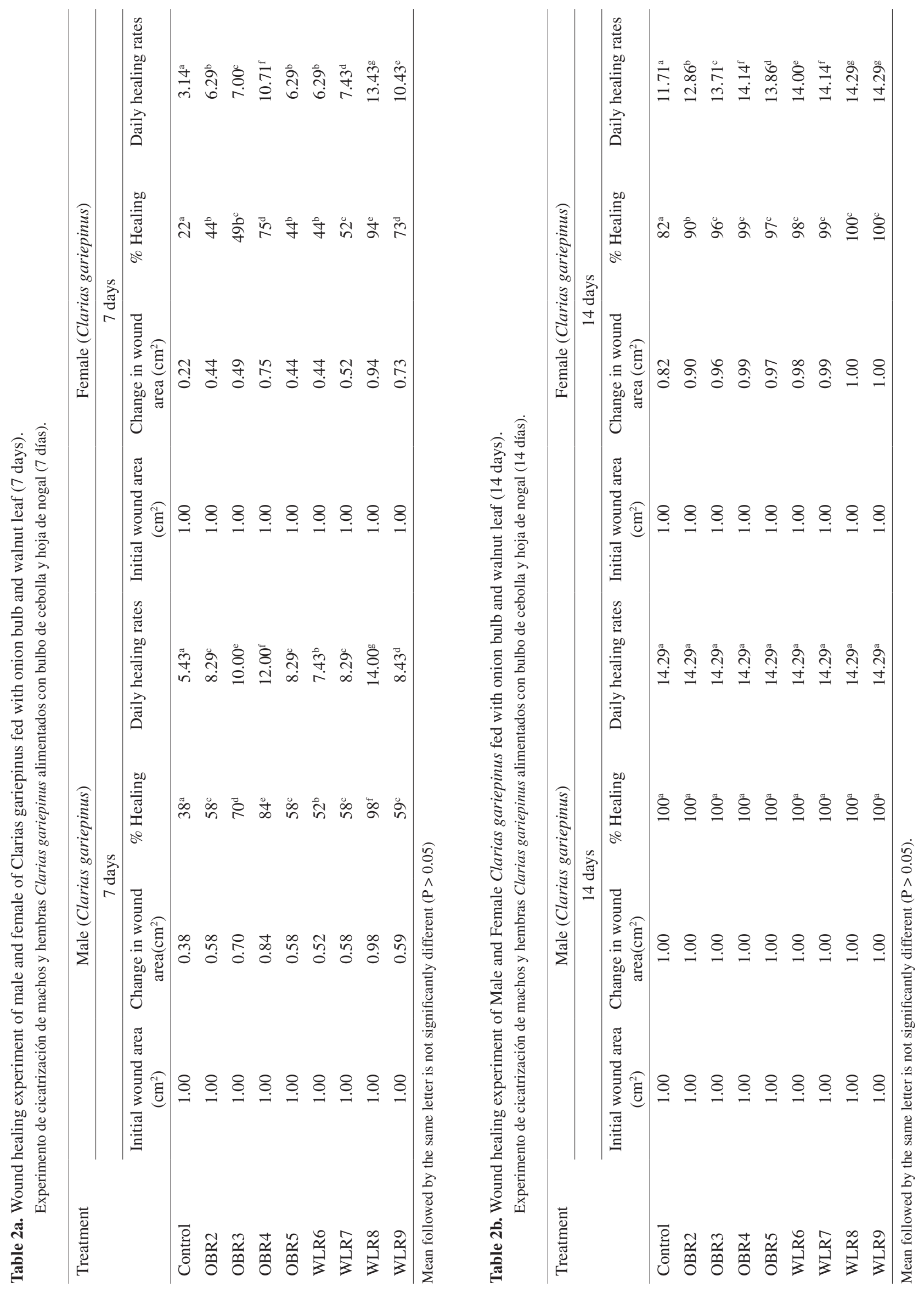
shows that the highest value was recorded in $\mathrm{OB} 4$ and the lowest one in OB2 and OB5 among the onion bulb residue treatments, while the highest value was recorded in WL8 and lowest in WL6 among the walnut leaf residue treatments for percentage healing. The highest value were also recorded in OB4 and lowest in OB2 and OB5 among the onion bulb residue treatments for daily healing rate and the highest value was obtained in WL8 and the lowest in WL6 for walnut leaf residue treatments on daily healing rate on the 7 days and $100 \%, 14.29$ on the 14 days of healing percentage and daily healing rate, respectively.

In addition, the result of percentage healing was similar to that of the male in both onion and walnut treated groups. The highest value was recorded in OB4 and the lowest in OB2 and OB5 among the onion bulb residue for daily healing rate and the highest value was recorded in WL8 and the lowest was recorded in WL6 for walnut leaf residue for daily healing rate on the 7 days OB4 recorded highest percentage healing and the lowest in OB2 among onion bulb residue treatments while highest value was recorded in WL8 and WL9 and the lowest value was recorded in WL6 among the walnut leaf residue treatments for percentage healing while the highest value was recorded in OB4 and lowest in OB2 among the onion bulb residue for daily healing rate and the highest value was recorded in WL8 and WL9 and the lowest in WL6 for walnut leaf residue for daily healing rate on the 14 days.

Percentage healing and daily healing rate at 7 and 14 days on lateral part and caudal part were significantly higher $(\mathrm{P}<0.05)$ than the control. Also, the male and female percentage healing and daily healing rate respectively at 7 and 14 days on lateral part and caudal part were significantly higher $(\mathrm{P}<0.05)$ than the control. Among the treated groups, walnut leaf were more effective than onion bulb treatment most especially WLT 8 which had complete healing on $6^{\text {th }}$ day and without any traces of scar on the $9^{\text {th }}$ day while other treated groups had their complete healing from $10^{\text {th }}$ day with or without scar, but the control had complete healing on $12^{\text {th }}$ day with slight traces of scar on the $14^{\text {th }}$ day.

\section{DISCUSSION}

Wound healing is a complex and dynamic process of restoring cellular structures and tissue layers in damaged tissues as closely as possible to its normal state. Wound contracture is a process that occurs throughout the healing process, starting with the fibroblastic stage whereby the area of the wound undergoes shrinkage. In the maturational phase, the final phase of wound healing, the wound undergoes contraction resulting in a smaller amount of apparent scar tissue. Granulation tissue formed in the final part of the proliferative phase is primarily composed of fibroblasts, collagen, edema and new small blood vessels.
These observation were similar to the report of higher percentage of wound closure observed in the group of animals treated with Saba florida on day 24 of the experiment (Omale and Isaac 2010) and those treated with Euphorbia heterophylla (Euphorbiaceae) leaf extract (Omale and Emmanuel 2010). This finding suggests that walnut leaves treatment may be more effective in dermal wound healing than the onion bulb. This may be due to presence of more antimicrobial constituents in walnut leaf than the onion bulb. One of the phytochemical constituents present in $T$. conophorum and A .cepa may be responsible for the wound-healing activity. Studies on T. conophorum and $A$.cepa have shown that phytochemical constituents like flavonoids, tannins, saponins and alkaloids were present and these are known to promote wound healing process mainly due to their astringent and antimicrobial properties, which appears to be responsible for wound contraction and increased rate of epithelization.

The findings also showed that healing percentage and daily healing rate were better healed on the lateral part than the caudal part. The reason may be due to presence of more flesh on the lateral part than the caudal part which had lesser flesh. The finding shows that the treated groups healed faster than the control. The higher healing percentage observed in the male in both onion and walnut treated groups may be due to the anabolic hormonal influences in the male. The possible reason why walnut leaf treatment performed better than the onion bulb treatment and the control may be due to high quality of wound healing properties, antimicrobial properties and growth promoting effect present in walnut leaf.

In conclusion, dietary supplementation of walnut leaf and onion bulb residues at all inclusion levels investigated has enhancing effects on dermal wound healing of $C$. gariepinus. Walnut leaf and onion bulb residues as feed ingredients could be a useful factor in Clarias gariepinus culture practices and $1.5 \%$ inclusion of walnut leaf residue in the diet of $C$. gariepinus would significantly aid the aquaculture industry by reducing mortality associated with wound infection.

\section{REFERENCES}

Abo A, JAO Olugbuyiro, SA Famakinde. 2004. Anti- infective and wound healing properties of Flabellaria paniculata. Afr J Biomed Res 7, 85-87.

Ajaiyeoba EO, DA Fadare. 2006. Antimicrobial potential of extracts and fractions of the African walnut - Tetracarpidium conophorum. Afr J Biotechnol 5, 2322-2325.

Azu NC, RA Onyeagba. 2007. Antimicrobial properties of extracts of Allium cepa (Onions) and Zingiber officinale (Ginger) on Escherichia coli, Salmonella typhi, and Bacillus subtilis. Internet J Trop Med 3, 2.

Bell JJ. 2002. Regeneration rates of a sub-lithoral demosponge. J Mar Biol Assoc UK 82, 169 -170.

Gonzalez SF, K Buchmann, ME Nielsen. 2007. Real-time gene expression analysis in carp (Cyprinus carpio L.) skin: in- 
flammatory responses caused by the ectoparasite Ichthyophthirius multifiliis. Fish Shellfish immune 22, 641-650.

Gonzalez SF, N Chatziandreou, ME Nielsen, W Li, J Rogers, R Taylor. 2007. Cutaneous immune responses in the common carp detected using transcript analysis. Mol Immunol 44, 1664-1679.

Ingold WM. 1993. Wound therapy: growth factors as agents to promote healing. Trends Biotechnol 11, 387-392.

Lazarus GS, DM Cooper, DR Knighton, DJ Margolis, RE Pecoraro, G Rodeheaver, MC Robson. 1994. Definitions and guidelines for assessment of wounds and evaluation of healing, Arch Dermatol 130, 489-493.

Lee Y, D Hami, S De Val, B Kagermeier-Schenk, AA Wills, BL Black. 2009. Maintenance of blastemal proliferation by functionally diverse epidermis in regenerating zebra fish fins. Dev Biol 331, 270-280.

Nakatani Y, A Kawakami A Kudo. 2007. Cellular and molecular processes of regeneration, with special emphasis on fish fins. Dev Growth Differ 49, 145-154.

Omale J, AV Isaac. 2010. Excision and incision wound healing potential of Saba florida (Benth) leaf extract in Rattus novergicus, Int J Pharm Biomed Res 1, 101-107

Sai KP, M Babu. 1998. Traditional medicine and practices in burn care: need for newer scientific perspectives. Burns 24, 387-388.

Yoshinari N, T Ishida, A Kudo, A Kawakami. 2009. Gene expression and functional analysis of zebra fish larval fin fold regeneration. Dev Biol 325, 71-81. 
